\title{
There is rebellion afoot, and revelry: the nascent reformation of intellectual integrity within south african universities 1
}

\author{
Christo Lombaard \\ Christian Spirituality, UNISA
}

\begin{abstract}
Across the world, the "university is infested by the managerialist cultures of strategic planning, staff appraisal and quality control" (Waters, 2000:xiii). The way in which the role of the ViceChancellor has in practice come to be defined, namely as a medium term managing director, is perhaps a prime example of this trend. This is the case too with many South African universities. Particularly at the bilingual universities (that is, the former Afrikaans language universities), academics have been managed into carrying an unduly large administrative and lecturing load, and as such are unhealthy for the academic integrity of the university. In this paper, this state of affairs is briefly described, and some signs are indicated which show a growing sense of resistance against these developments. The classic role of the academic remains the most valuable to the university and to society.
\end{abstract}

Key words: the nature of the university; intellectual integrity; academic freedom in South Africa.

\section{Acting in character}

Clearly, being in flux is, and always has been, one of the universal characteristics of the university (cf. e.g. the essays collected in Teather, 1999). Panta rei - everything moves - (Lategan, 1996:57) is natural and to be expected, because, in a sense, "(e)lke universiteit word deur 'n bepaalde samelewing tot stand gebring en in stand gehou"2 (Dreyer, 1982:18). Just as valid, though, is the converse: that universities shape their societies. It is for precisely this reason that, almost constant strains notwithstanding, societies continue to hold universities in high esteem: "Dat relevansie as ' $n$ eis beklemtoon word, is in sekere mate juis aan die sukses van die universiteit toe te skryf'3 (Rossouw, 1993:35; cf. P. du Toit, 1989:126). This point may even be taken a step further: that good universities tend to elicit the kind of response we see repeatedly, that the university must be relevant.

Still, this does not mean that, resting on their laurels, calls for greater relevance should be ignored by universities. Such demands are seldom frivolous - societal powers that issue them mean business, and often have it in their power seriously to hurt the university. Insistence on relevance must elicit both introspection and response. That is what it means to be dialogically answerable, institutionally accountable and socially responsible.

1 Paper read at the "Re-inventing the university" conference, 5-8 Dec. 2004, Rhodes University.

2 Translation: "each university is brought into existence and is kept going by a certain kind of society".

3 Translation: "That relevance is emphasised as a demand, is to a certain extent ascribable to the success of the university [as an institution]." 
The resources on which the university may draw in order to play to the fullest its role in society, and to stave off political authorities and the economic establishment who may over-play their hand, are nothing other than the historically conditioned characteristics of the university ${ }^{4}$. These earlyestablished characteristics may be summarised (following Wethmar, 1996:477-481) as follows:

- Universality, which relates both to who may learn, namely anybody, and where the awarded degree subsequently allows them to work, namely anywhere;

- Diversity, which refers not only to the scope of subjects taught, but also to the variety of approaches to those subjects;

- Community service, understood not as is presently the case in South Africa as consultancy work outside the university ${ }^{5}$, but more professionally, directly related to the profession of teaching. In the first centuries of the university's existence, students could after completion of the artes liberales progress to medicine, law or theology 6 . In all three cases, these specialisations would serve society directly by protecting hoi polloi (the many / the multitudes / the people) against the harms of, respectively, disease, injustice, and hell. The academy was in and by itself understood to be community service. This is a perspective that could fruitfully be reclaimed for modern universities;

- Freedom and loneliness: The above stated fundamental commitments led in the nineteenth century to idealistic principles of the university (as developed by Newman, von Humboldt, Fichte and Jaspers), which were a response to the views that have over time taken hold of the university as an instrument of state. In opposition, academic freedom and academic loneliness were set as norms - not to be understood as being uninterested in society, but as being disinterested, in order best (i.e. critically) to serve humanity. Thus, the intellectual enrichment of the individual by means of study remains in itself a noble goal ${ }^{7}$. At the same time, though, scholarship is intrinsically an ethical affair.

The sense of greater purpose gained from working to these principles, is something quite different from what may well be the case with less skilled occupations. Such idealism is typical of many professions; an academic career, though, may be one of the few professions in which this idealism can be sustained. What is required, however, is that one should at least be aware of these foundations to the university as an institution.

4 Despite criticism of this approach, such as that by Duke 1992:xi-xii, I too begin with the fundamentals of what a university is, and what a university should be in order best to serve society. There is no other way to think essentially about the university; this is the resource from which to analyse its present state. These traditional characteristics also find reflection in the local university community - cf. Lickindorff, 1995:418.

5 In one case at a local university, academic staff were at the beginning of this year encouraged by a Dean to undertake such work with explicit reference to the poor remuneration of lecturers at South African universities.

6 The college-university system in the USA is a close modern parallel.

7 For knowledge as its own best feature, see the classically liberal view of the university we find in Newman, 1999/1852:91-112, a view that was eminently sensitive to context - cf. Newman, 1999/1852:435-456). 


\section{The powers that be}

While, in South Africa, all government reports on the universities have accepted relative autonomy ${ }^{8}$ as a necessary part to academic pursuits (Dlamini, 2000:172), the way this "relative" is viewed, certainly comes with strings - and these include purse strings ${ }^{9}-$ attached. Parallel to the way governments rhetorically employ the term "responsibility" to suggest the way they would like the press to report on state matters, the word "accountability" is affixed to official formulations on universities' institutional autonomy / academic freedom. In both cases, the power to interpret the term is an area of political and legal contestation, with, in the case of universities, "co-operative governance" being the expression/technique with which the South African state currently seeks to exert influence (Dlamini, 2000:172-175).

With "relevance" in our time defined primarily by politics and economics, the role of the university becomes, in a politically acceptable way, the production of a trained labour for the marketplace (cf. e.g. Bolsman \& Uys, 2001:173-175) ${ }^{10}$. Therefore, the state can, by way of the present funding system, interfere directly with which courses are taught at which universities (Dlamini, 2000:175) ${ }^{11}$. A prime current example is the withdrawal of funding for Mining Engineering at the University of Pretoria (UP), when government saw fit that this degree should be taught at the University of the Witwatersrand (Wits) alone (Jansen, 2004a:6). In addition, when a R56 million cut in subsidy to UP was announced by government, the response has been simply to manage this new financial reality internally. With the Vice-Chancellor understood as a manager and not a protector of the university (see below), there is little likelihood of an immediate and public response to such a funding cut, such as declaring it in principle unacceptable or in practice detrimental to the quality of the university.

8 The autonomy of the university is summarised, with reference to TB Davie, again most recently by Jansen 2004a:2 as the freedom to "decide who shall teach, what we teach, how we teach, and whom we teach" (a matrix of analysis that recurs widely, and hence remains the parameters of discussion about the future of the university too - cf. e.g. Johnstone, 1999:243-248 - yet is not at all simple and static - cf. A. du Toit, 2000:76-133; so too Rossouw, 1993:31).

9 Cf. Dlamini, 2001a:361. On the way this has played out locally, Jansen 2004b:1-2 remarks: "the great paradox of our times is that as the distance between the state and the university shrinks in political terms (the autonomy debate), that distance widens in financial terms (the subsidy debate). In other words, the state demands more through direct intervention even as it gives less in terms of financial commitment. Again, this is a global phenomenon..." Bolsman \& Uys, 2001:174 appropriate the concept of "double transition" to explain this relationship between state funding and state involvement in universities.

10 See Redelinghuys, 1986 for a principled stand, by remaining true to the traditional role of the university, against what has been termed the "multiversity" (Von Blum, 1986:1-18, among others, drawing on Kerr, 1963) catering solely to market and political requirements.

11 This stands in direct contradiction to the view expressed by Badat, 2004:19, who states that "State involvement must be predicated on a fundamental commitment and respectful adherence to the principles of institutional autonomy and academic freedom, as necessary conditions for optimising the contribution of institutions to economic and social development and a substantive democracy. This is notwithstanding the necessity equally for public accountability on the part of institutions." 
If universities themselves continue to respond to such interference as would a section of a business, by quietly accepting whatever is allocated by the authorities and managing to prescribed form, government cannot be expected so see universities any differently. After listing instances in which the post-1994 government in South Africa has encroached on universities' autonomy (Jansen, 2004a:6-8; cf. also Dlamini, 2000:176-197), Jansen goes ahead to ask the question (Jansen, 2004a:11) - I paraphrase - what next?

\section{This is the dawning of the age of the manager}

However, broader cultural trends influence the university too, in quite natural ways. An international example at present is the way in which the "university is infested by the managerialist cultures of strategic planning, staff appraisal and quality control" (Waters, 2000:xiii) ${ }^{12}$. This dynamic has been explained with reference to the role of Deans. In our time, Deans are more inclined to manage colleagues on behalf of persons higher up in the university structure, rather than in the first instance to carry out departmental colleagues' decisions (Pauw, 2004:4; A. du Toit, 2001:6; cf. Jansen, 2004b:4). Yet, it may be in the role of the Vice-Chancellor that we see most clearly the modern managerialist culture re-forming universities.

Vice-Chancellors are at present appointed for a medium term contract to lead universities. During the term in office, certain agreed-on strategic objectives have to be met in order for the incumbent to be regarded as a "good" Vice-Chancellor. This means, per definition, that structural alterations have to be pushed through the organisation of the university. That is, in some way, the essence of the appointment contract. Targets have to be met ("sales talk", if ever there was).

A "good" Vice-Chancellor, thus, initiates and manages change. For everybody lower down the hierarchy, this means that whatever is currently being promoted from "on high" has to be "cascaded" down. Deans, Heads of Department and lecturers ${ }^{13}$ are cogs in a wheel turning to managerial engines. Each new Vice-Chancellor brings new adjustments, most often in the form of altered/added administrative requirements. The role of the Vice-Chancellor as representative of the community of academics towards broader society (government, business and the like) thus does not feature prominently. Put differently: a Vice-Chancellor is in no strong sense a protector of the university against undue influence from its surroundings (be they "constitutional, statutory, social or political" - Dlamini, 2000:176), nor even an outward symbol to society of credible stability and academic integrity. Rather, the main course of the Vice-Chancellor's influence seems to be in the opposite

12 Jansen, 2004a:3: "There are new global conditions that recast this relationship in very similar terms across nation states; the rise in what some call new public management and others new managerialism is in fact an institutional response to transnational conditions imposed on national economies and polities. The national obsession with institutional audits, performance based contracts, efficiency-driven restructuring and the like have direct consequences for how institutions (and the state) think about and respond to questions of autonomy; the double entendre reflected in the title of this Lecture is intended: we are in the awkward position of accounting for autonomy."

13 Note how, instinctively, the bureaucratic titles tend to be capitalised, and the academic ones not - already an indication of where the weight lies in our university culture. 
direction: it is through this office that the dominant cultural streams of society enter the university most influentially.

This is most noticeably the case in South Africa's bilingual universities (i.e., the formerly Afrikaans language universities), where academics have been managed into carrying unduly large administrative and lecturing loads. Because Afrikaans culture tends to value administrative rather than critical skills highly, these universities have been characterised by a strongly managerialist style of governance (so too Sellschop, 1995:32). Hence, increased administration is borne with a grin the Calvinist work ethic ensures that dissent will be minimal and quiet. A case in point was the rewriting of the entire university curriculum in Outcomes Based Education (OBE) format. While the English universities were debating this mode of teaching being forced upon the education system, the bilingual universities swallowed any concerns and submitted the documents as prescribed and on time. (Historically Disadvantaged Institutions also tended to toe the OBE line very quickly, which raises the more general possibility that those universities which felt themselves most vulnerable were least likely to dissent. This, in itself, offers an interesting line of further, comparative investigation into the psychology of a sense of universities' autonomy...)

The difference between these "language cultures" was being shown again with the merger of the Rand Afrikaans University (RAU) and the Technikon Witwatersrand. The staff-student ratio was much more favourable at the latter, even though one would expect the university, rather than the technikon, to have had fewer students per staff member. Furthermore, the fact that RAU was a bilingual institution would also lead one to expect a greater number of, at least, lecturing staff. However, the five bilingual universities had not received additional resources to support the added lecturing and administrative (such as translation) obligations. None protested loudly or publicly to the Minister or the Department of Education about this. The costs of adding English, like those of OBE, had simply been managed away, often in the face of dwindling subsidies and increased student numbers. Lecturers are simply expected to duplicate lessons where the need arises, and they do. Nobody ever says no ${ }^{14}$.

This fits well with managerialist thinking. The university is an organisation, and leadership means organising it - all very business-like. However, these unreflected cultural reflexes are based on long-discredited positivist ideology, a manner of thinking, overseeing and administering that employs graphs and numbers (Visagie, 1990:123) ${ }^{15}$, and talks incessantly of "planning, leading, organising and controlling" (D. du Toit, 2004:1; cf. P. du Toit, 1989:126-127).

14 Apart from the Afrikaans cultural dimensions to this convention, another factor that has to be kept in mind when considering the broader social sphere, is that there is a sense within the Afrikaans universities of being at the mercy of the new government. These universities have no "struggle credentials" to place them on a firm political footing of unquestionable legitimacy (hence the search for Beyers Naudés and Bram Fischers to pay homage to with honorary doctorates - see e.g. Joubert, 2004:14; Giliomee, 2004:I; Die Vrye Afrikaan-Intussen, 2004). There seems to be, among the rank and file at least, a vague sense of insecurity: is there a possibility that we can be closed down? "Ja, baas" seems to be the only response within these universities, and by these universities, with which is reacted towards government, publicly at least.

15 As an example: at UNISA a time management system linked to the desk top computers of academics has them clocking in and out in order to prove that a set minimum of their hours per week is being spent on 
This fundamentally disregards the reality that "(u)niversity teachers and researchers are professionals" (Pauw, 2004:1), and professionals of a very particular kind. Not motivated primarily by either money or the urge to please the boss, intellectuals appraise themselves internally (i.e., personally) by their sense of participation in knowledge and scholarship, and externally (i.e., socially) by the estimation of their peers. Such "'(h)igh-trust' posts are those carried out largely outside the presence of management or supervisory staff" (Giddens, 1991:19; cf. P. du Toit, 1989:127). In my experience, being managed and administered detracts both from the professional/professorial activities and from the sense of fulfilment of academics ${ }^{16}$. Academics shouldering too large an administrative load and having to cater to ever more altered practices being "cascaded" through the institution, is therefore unhealthy for the academic integrity of the university. Yet, culturally and too uncritically, we have been bequeathed management models from the factory floor, applied with hardly any variation, to the academic milieu. It seems white collars are viewed as, simply, super blue.

Hierarchical bureaucratic structures, as opposed to collegial university government (for an overview of different ways in which this college may function cf. Hardy 1990:20-41; also A. du Toit, 2001:6), do not particularly encourage the production of new ideas. University management remains confronted with a complex array of philosophical and practical questions, as Badat, 2004:18 points out: "how are we to build an institutional culture and configure internal governance in a way that holds fast to the values of institutional autonomy, academic freedom, academic self-rule and democracy, that concomitantly addresses the requirements for public accountability, efficiency and effectiveness, and that avoids an ideology and culture of 'managerialism'", and new ideas are what the university is all about (Pauw, 2004:1-2; cf. Bolsman \& Uys, 2001:174). It was precisely against stagnation in the production of ideas at universities that Friedrich Nietzsche (1999/1883:161) wrote "Von den Gelehrten":

Gleich Solchen, die auf der Strasse stehn und die Leute angaffen, welche vorübergehn: also warten sie auch und gaffen Gedanken an, die Andre gedacht haben. ${ }^{19}$

campus. Somehow, reference to hours and location is regarded as good academic management... However, the amount of time spent administering (and at times, plainly, cheating) this system, already detracts from its worth. The arrangement is wholly counter-productive if one considers that those academics who would abuse a freer system are doing so in any case, and those who would work conscientiously when structured very loosely still do so, but now with a bad attitude.

16 As another instance: the requirement by government that each university should have a quality assurance bureau (see Dlamini, 2000:182 on the Higher Education Qaulity Committee of the Council for Higher Education) may be well intentioned, but I believe is doomed to failure. Even in the United Kingdom, which has the most extensive university teaching and research assessment programmes, the evaluation processes most often simply distort what it should be encouraging: teaching and research (cf. Smith, 1999:159-163). What is more, these managerial processes plainly create the impression that the state and the university leadership put insufficient trust in lecturers-researchers and in the universities' academic processes that create intellectuals. Quality control is a concept derived from the factory floor. To apply it in this way to university life is clearly a misappropriation of the concept. The existing informal and academically quite natural peer respect remains in my view the best quality control process for academics.

19 "Like those who stand on the street and gape at the people going by: so too they wait and gape at ideas others have thought". 


\section{Vital signs...?}

However, a few signs and possibilities have come to my attention, which may indicate, or encourage, something of a rebellion against both too strong government intervention and too strong internal management styles (cf. Badat, 2004:20). I list eight:

\subsection{First refusal}

Some faculties at UP have recently gone through extensive evaluation exercises. For the persons who led these exercises within the respective faculties, it required three month's highly intensive administration. When, on the recent appointment of a new head to the university's quality assurance office, rumours surfaced that these exercises might have to be repeated, a word hardly ever heard at UP - "weier" 20 - was suddenly being used. Has breaking point in the administrative load been reached?

\subsection{Tendering tenure}

A locally minor, but potentially very influential, strand of thought on academic freedom relates to the matter of tenure, as currently found most commonly in the USA (A. du Toit, 2001:7). If this issue could be pushed to the fore, and perhaps become an institutionalised part of South African university life, much will have been gained in assuring the long-term health of local universities. Tenured professorships are much less susceptible to political, economic and cultural harassment than any other categories of academic appointment. The "diagnosis of the university" (Pelikan, 1992:191) would through steps such as these become much more optimistic.

\subsection{Tanks off the lawn!}

Because the state seems to consider universities its "property"21, it is without much trouble that the Minister of Finance could in Parliament threaten to cut the funding of university departments of, by name, Biblical Studies; more recently, the State President questioned the relevance of Sociology 22 . Whereas the former could be related to the present government's (lack of) policy on religion (cf. Lombaard, 2001:17-24), the latter is new to South Africa, but was well-known in the UK during the time the present State President and Finance Minister studied there (cf. Duke, 1992:112).

Whereas theologians generally held their heads low and hoped for the passing of this cup 23 , sociologists had initially been more active, with discussions among the Gauteng leadership of the South African Sociology Association about writing a letter of objection to the State President. However, for now at least, it seems that little has come of these intentions. This slight advance in not enough, though. If a healthy distance were to remain between government and universities,

20 Translation: "refuse".

21 De jure South African universities are organs of state, though of a special kind, and protected by the Bill of Rights - cf. Dlamini, 2000:172-173, 177-178.

22 The fact that HF Verwoerd held the first chair in Sociology in the country seems to have passed the State President by.

23 Signs are strong that this cup has indeed passed. 
any such pronouncements should attract fierce reactions from the South African Universities ViceChancellors Association (SAUVCA) and from the relevant academic societies.

A goal would be the kind of academic ambience that made it possible for the president of Trinity College, Oxford, recently to react to suggested university entry policies of the British Department of Education, by telling it to "take its tanks off Oxford's lawns", and then seriously to threaten withdrawal from the state university system, in order to become a private university (THES Daily Newsletter, 6 Oct. 2004).

\subsection{How the state was won (UNISA 1)}

We had a recent instance similar to this is South Africa, when the Council of the University of South Africa (UNISA) went ahead and appointed its present Vice-Chancellor ${ }^{24}$, despite vigorous objections by the previous Minister of Education, and later even serious threats to withhold its state funding. As it transpired, UNISA got both its Vice-Chancellor and its usual subsidy.

\subsection{Paradigm regained (UNISA 2)}

On the $6^{\text {th }}$ of October 2004, a small seminar titled "Managing a university today" was held at UNISA, primarily for UNISA staff, and attended by, mostly, academics. Three short papers were presented (D. du Toit, 2004; Pretorius, 2004; Pauw, 2004), after which a wide-ranging discussion was held. Here, as in many previous instances, I was amazed at how little many (most?) academics think about the fundamentals of what they occupy their professional lives with: the essence of the university, the craft of the intellectual, and the roles of the university and the academic in society. Equally surprising, though in a more pleasant sense, was how these fundamentals, when pointed out, resonated with the audience. It is as if a sense of purpose dawned on many of those present - vague awarenesses are put to language, giving greater purpose to what may have become for some just a humdrum old job. Unfortunately, it was only in the last minute that the so-what-dowe-now-do-about-this? question was posed, leaving room for only the rather bland consciousnesshas-been-raised answer. However, a few more academics have been given a broader understanding of their labours, and whence their further debate may lead, institutionally, remains to be seen.

\subsection{Paradigm lost (UNISA 3)}

Moments of enlightened independence at UNISA, as indicated in 4.4 above, have however been contradicted in the more recent past, with the appointment to the same institution of the former Haitian Presidential couple. However much the three documents in the public domain ${ }^{25}$ may seek to change this, one cannot escape the sense that in this instance, the South African university system has been abused:

Whichever way past and present political processes in Haiti related to Mr Aristide may be regarded, the manner of the appointment of the Aristides to UNISA raises troubling questions. Have these appointments come about by means of the political connectedness of the Vice-Chancellor of UNISA?

24 Personally, I have strong reservations about appointing somebody from outside the university sphere to a Vice-Chancellorship. This is akin to appointing a managing director to a publicly held company, and too far removed from the tradition of the Vice-Chancellor as primus inter pares.

25 These are listed in the Bibliography as UNISA, 2004a, UNISA, 2004b and UNISA, 2004c. 
If so, it seems that a local university can become a holding space for anyone benefiting from the present government's goodwill ${ }^{26}$. Ignoring the respectful distance that should exist between state and university, appointments to the latter (both Mr and Mrs Aristide were appointed to research fellowships) may come about as a favour on a whispered government/political request. Of course, this may not be the case. However, the impression of undue political influence cannot be escaped: three weeks' worth of repeated inquiries to the UNISA leadership on who first suggested the Aristide appointments were met with, first, the telephonic response "Why do I smell a rat? ", and concluded with "We fail to see the relevance of the question" (UNISA, 2004d).

Colleagues at UNISA have been discouraged from asking such questions. The press release, the answers to Parliamentary questions, the minutes of the relevant meeting, and written and oral requests cannot give clarity on who within UNISA initiated the processes leading to these appointments. Would a daring guess then be in order? Could it be that the direct line of communication ran from the President of the country to the Principal of the university?

Clearly, here is a case on which the academics at UNISA could have taken strong action - it is a fight for asserting the university's autonomy they could hardly lose. Yet, no action was taken ${ }^{27}$. UNISA's long-standing and meandering racial tensions are further fuelled by this. Academics in the Faculty of Theology, where Mr Aristide has been placed, have to countenance burly security guards with something bulging under the arm. At least one colleague has had to endure snifferdogs going through her office. This is hardly an atmosphere conducive to free academic exchange.

I am convinced government does not realise what has fundamentally been done not only to UNISA, but to the whole of the South African university system, with these appointments. One of the marks of a free society is that the universities can keep government at bay - formulated in more traditional terms: where the autonomy of the universities from the state is fiercely protected. The fact that government channels funds to universities 28 does not give it the right to run the universities. A government committed to democratic processes in society would resist the impulses that come with power to extend its influence into all public spheres. A society that values its freedom would not tolerate such influence. A university that is aware of and committed to its historically-conditioned and fundamental role in society would rebel against being managed as just another of the "branches of the civil service" (to borrow a phrase from Duke, 1992:2, which, interestingly, recurs in SAUVCA, 2004:14).

If the suspected link \{government / political official $\}$ - \{senior UNISA official(s) $\}$ - \{appointment of Aristides\} in time proves to be accurate, this may well constitute the most serious case of improper government interference in a South African university of which I am aware. If not the UNISA academics, why are the rest of the South African university community not coming out

26 The question has been asked, both inside UNISA and out, always informally, usually tongue-in-cheek: "Who's next - Mugabe?, Castro?, Bin Ladin?, Bush?".

27 It is "difficult to regain lost ground" (Jansen, 2004a:11)...

28 "...subsidies granted by the government to the universities do not belong to the government but to the taxpayer; the government merely acts as a trustee, and as such should discharge this trust impartially and without taking into account irrelevant considerations" - Dlamini, 2000:175. 
more strongly on this matter? ${ }^{29}$ In February 2004, when the government of France made comparatively minor adjustments to financing the arts and sciences, intellectuals reacted strongly and publicly, through the media and a petition signed - as reported by the THES Daily Newsletter of 18 Feb. 2004 - by "artists, thinkers, film-makers, scientists, lawyers, doctors and academics" etc., against what they called "la guerre à l'intelligence ${ }^{130}$. How much government interference in the South Africa universities will it take before we declare it a war on intelligence? When comes the time for a Unilateral Declaration of Independence? Is a solution for academics committed to the ideals of an autonomous university, i.e. free from too great an extent of state interference in the university's life, to revive the early university habit of (threatening) secession (cf. Dunbabin, 1999:34-35)? In time, the recent growth of universities outside the local state system (cf. Brown 1998:59-61), such as Monash University in Midrand, St. Augustine's Catholic College in Johannesburg, and discussions on a possible Afrikaans language university in Oudtshoorn, might be read as forms of such secession.

It would do us well to remember that "(t)he university pre-dates the nation state as we know it" (Sayer, 1999:83; cf. Pister, 1999:229-230), and - one might conjecture - will probably outlive it too. As history has shown, tension between university and state has always been part of the university's existence (cf. e.g. Verger, 1978:134-137), and here in Africa too, it is not been too difficult for a particular government even to destroy universities within the ambit of their power (cf. e.g. Dlamini, 2002:75-98).

\subsection{We'll do it their way?}

One way of ensuring - one could say, reclaiming 31 - greater institutional autonomy for South African universities, is to follow the German example of the early 1970s (cf. Dlamini, 2001b:5051). In that case, legal recourse was taken, resulting in a Constitutional Court decision in which the state is required to take active measures to ensure by institutional means that academic freedom is guaranteed. Rather than the case we have at present, where one sees the state constantly encroaching on the university's terrain, we would have the state working actively to keep itself off the grass. The wellbeing such a process would inject into civil society would be a welcome change. The first signs that this may be in the offing, in one way or another, is indicated by Ndebele (2004:2), who speaks of "a 'high-noon syndrome' as Vice-Chancellors began to talk about looking for issues on which to challenge the state in a big way."

\subsection{Write all about it}

Another way of promoting the necessary autonomy of the university, would be more vigorous debate on these matters, not only in the academic sphere, but also through more public avenues, such as the press. Of course, this has already happened (see e.g. Bisseker, 1997:40; Financial Mail

29 Cf. Jansen 2004a:12: "... the infringement of institutional autonomy will continue unless the higher education sector as a whole begins to speak with one voice ... Unless the leadership of the higher education sector finds a strategy to speak with one, binding voice on the question of autonomy as a common interest, it will continue to loose ground on the right to decide on core academic matters."

30 The petition titled Appel contre la guerre à l'intelligence is available at: www.lesinrocks.com/inrocks/galeries/appel/appel.html.

31 "The loss of autonomy, like the loss of virginity is, as far as I know, not recoverable once given up" (Jansen, 2004a:11) - a metaphor which may, of course, be formulated in less polite ways too. Still, with reference to Court, 2001:3-22, the road of the reconstruction of a university may, though arduous, be possible. 
1997:24, Mischke, 2004:16; Lombaard, 2005:iii). The greater the general awareness of the role universities should play and have played in society, the greater the informed public support one can expect in times of trouble.

\section{5. "Myth", in conclusion}

Usually, when the autonomy of the university is referred to as a "myth", the reference is to the popular use of the term, as something unattainable or unreal (cf. e.g. Dlamini, 2002:97). However, "myths" as understood in psychological, anthropological and other more technical denotations, are those truths by which (a group of) humans live - the foundational norms and values by which we lead our lives, understand ourselves and explain our existence. In this sense, "autonomy" and "academic freedom" constitute part of the myths of the university ${ }^{32}$. Without these myths, the university is bereft of its identity and, hence, its role in our cultural universe.

Moreover, myths never act alone; they tend to clique together, and such clusters of myths compete with one another. In our time, ever more seriously, the modern myths of political relevance and economic functionality, which serve the twin gods of power and money, threaten to replace the traditional myths of the university. Should such substitution be successful, the university will have died (cf. Jansen, 2004a:16) ${ }^{33}$.

Ironically, neither the political nor the economic welfare of society (not to mention all the other aspects of culture) will be well served by such a demise (cf. Adedeji, 1998:64). These raising Cains will not gain Eden by killing off able universities. Already in the thirteenth century part of the role ascribed to the university was to set limitations to powerful institutions of the day - the state and the church - for the benefit of the greater community (Wethmar, 1996:476-477). The institutions of power have changed in our time, to the state and the economy ${ }^{34}$. Still, the role of the university as defensor populi 35 remains. Put differently, for our purposes: defending the university proper is also protecting society against its own worst systemic impulses. This is by no means a simple undertaking (cf. Visagie, 1990:116-128); it is nevertheless our civic duty.

32 Such myths are formulated in somewhat related but more specified ways, with different terminology, such as the "kenmerkende elemente" (identity markers) of the university as formulated by Wethmar, 1996:477481, or the "ideals" as formulated by Visagie, 1990:122, or the "doelwitte" (goals) and "riglyne" (guidelines) as formulated by P. du Toit, 1989:131-134, or the "images" as formulated by Lategan, 1996:57-62, 64-70, or the "paradigmas" as formulated by Rossouw, 1993:25-30. I thus use "myth" here differently to the more or less historical use of the term in Shore, 1992.

33 Jansen, 2004a:16 states that a "university in which the entire place has been transformed into a commercial center, the departments called 'cost-centres' and the students called 'clients'; in which every "management" meeting is consumed with balancing the budget in the light of impending subsidy cuts; in which the response to external intervention is one of compliance and consent; in which the accumulation of larger and larger numbers of accredited publications is pursued with relentless vigour; in which teaching is equated with technology; and the mechanics of research confused with the elegance of scholarship. Just about everyone in such a place is in the business of (ac)counting. Here, too, the university has long ceased to exist."

34 Which is the more important, is part of the interesting debate on globalisation.

35 A somewhat subversive use of this phrase, since it has usually been reserved for the role of a senior official of either the state or the church, in both cases of Rome. 


\section{Bibliography}

Adedeji, A 1998. African renaissance, economic transformation and the role of the university. Indicator South Africa 15/2, Winter 1998, 64-68.

Appel contre la guerre à l 'intelligence 2004. www.lesinrocks.com/inrocks/galeries/appel/appel.html (website available until end of 2004; the article has been archived, i.a., at http:/www.assisesuniv-recherche.ouvaton.org/article.php3?id_article=53 ).

Badat, S 2004. 15 propositions on the critical issues and challenges facing South African higher education institutions in the second decade of democracy (Paper read at the Rhodes University Executive Management Bosberaad, Mpekweni Sun Hotel, Eastern Cape, 23-25 July 2004).

Bisseker, C 1997. Bengu tightens the screws on university autonomy. Financial Mail 146/4, 22 August 1997, 40.

Bolsman, C \& Uys, T 2001. Pre-empting the challenges of transformation and marketisation of higher education: a case study of the Rand Afrikaans University. Society in Transition 32/2, 173185.

Brown, D 1998. The tinkle of tertiary tills: private universities for South Africa? Indicator South Africa 15/1, Autumn 1998, 59-61.

Court, D 2001. Financing Higher Education in Africa: Makerere, the quiet revolution. Perspectives in Education 19/2, 3-22.

Die Vrye Afrikaan - Intussen 2004. Stellenbosch en die Idee van 'n Universiteit. www.vryeafrikaan.co.za, Vrydag 12 November 2004, 1/11.

Dlamini, CRM 2002. University autonomy and academic freedom in Africa: ex Africa semper aliquid novi? The Comparative and International Law Journal of Southern Africa XXXV/1, March 2002, 77-98.

Dlamini, CRM 2001a. University autonomy and academic freedom in transition: the British experience. SA Publiekreg / SA Public Law 16/1 \& 2, 343-361.

Dlamini, CRM 2001b. University autonomy and academic freedom in Germany: a lesson in transformation. Obiter 2001, 33-56.

Dlamini, CRM 2000. Limitations on and threats to university autonomy and academic freedom. Tydskrif vir Hedendaagse Romeins-Hollandse Reg / Journal of Contemporary Roman-Dutch Law 63, 171-199.

Dreyer, PS 1982. Die aard en taakstelling van die universiteit, in Nel, PG (red.) Die universiteit: verlede, hede en toekoms. Roodepoort: CUM-Boeke, 9-24.

Duke, C 1992. The learning university. Towards a new paradigm? Buckingham: The Society for Research into Higher Education \& Open University Press.

Dunbabin, J 1999. Universities c.1150 - c.1350, in Smith, D \& Langslow, AK (eds) The idea of a university (Higher Education Policy Series 51). London: Jessica Kingsley Publishers, 30-47.

Du Toit, A 2001. Revisiting academic freedom in post-apartheid South Africa: current issues and challenges. Commissioned paper: Editorial Group for "Transformation in Higher Education" book, CHET Board.

Du Toit, A 2000. From autonomy and accountably: academic freedom under threat in South Africa? Social Dynamics 26/1, 2000:76-133.

Du Toit, D 2004. The management of universities. "Managing a university today" seminar, UNISA, 6 October 2004.

Du Toit, P 1989. Die missie van die universiteit. Tydskrif vir Geestesweenskappe, Maart 1989, 123136. 
Financial Mail editorial 1997. University autonomy under threat. Financial Mail 146/12, 17 October 1997, 24.

Giddens, A 1991. Modernity and self-identity. Self and society in the late modern age. Stanford: Stanford University Press.

Giliomee, H 2004. Op soek na die ware gees van die US. Rapport (Perspektief), 7/11/2004,i.

Hardy, C 1990. Managing strategy in academic institutions: learning from Brazil. Berlin: Walter de Gruyter.

Jansen, JD 2004a. Accounting for Autonomy (41 ${ }^{\text {st }}$ TB Davie Memorial Lecture; 26 August 2004). University of Cape Town.

Jansen, JD 2004b. Why Tukkies does not have a Budget Deficit (University lecture, 27 October 2004). University of Pretoria.

Johnstone, DB 1999. The future of the university: reasonable predictions, hoped-for reforms, or technological possibilities?, in Brennan, J, Fedrowitz, J, Huber, M \& Shah, T (eds) What kind of university? International perspectives on knowledge, participation and governance.

Buckingham: The Society for Research into Higher Education \& Open University Press, 239250.

Joubert, J-J 2004. US in die greep van gedienstigheid. Beeld, 5/11/2004, 14.

Kerr, C 1963. The uses of the university. Cambridge, Massachusetts: Harvard University Press.

Lategan, LOK 1996. Images of the university: which image would best serve the interest of the university in South Africa? Tydskrif vir Christelike Wetenskap 32/1 \& 2, 56-72.

Lickindorff, E 1995. The dilemma of a common university identity in South Africa. Suid-Afrikaanse Tydskrif vir Wetenskap / South African Journal of Science 91, Sept. 1995, 418.

Lombaard, C 2005. Word ons universiteite hokgeslaan? Rapport (Perspektief), 23 Januarie 2005, iii.

Lombaard, C 2001. The left governing hand and the right governing hand: begging for a church without public hands? Journal of Theology for Southern Africa 109 (March 2001), 17-24.

Mischke, A 2004. Só word universiteite 'n bedreigde spesie. Rapport (Perspektief), 26 September 2004, 16.

Ndebele, N 2004. Higher education and political transition. IZWI Voice of HE Leadership, 2004/2 $\left(2^{\text {nd }}\right.$ Quarter) / www.chet.org.za/issues/Njabulo\%20Article.doc , 1-3.

Newman, JH 1999 (1852). The idea of a university, defined and illustrated (Gateway editions). Washington, D.C.: Regnery Publishing, Inc.

Nietzsche, FW 1999 (1883). Also sprach Zarathustra (Kritische Studienausgabe, Hrsg. Colli, G \& Montinari, M). Berlin: de Gruyter.

Pauw, JC 2004. Aspects of the feasibility of collegial managing and governing at a university. "Managing a university today" seminar, UNISA, 6 October 2004.

Pelikan, J 1992. The idea of the university. A reexamination. New Haven: Yale University Press.

Pister, KS 1999. The university of the future - place, progress or paradigm?, in Brennan, J, Fedrowitz, J, Huber, M \& Shah, T (eds) What kind of university? International perspectives on knowledge, participation and governance. Buckingham: The Society for Research into Higher Education \& Open University Press, 229-238.

Redelinghuys, HF 1986. Die veelsydige rol van die moderne universiteit / The multi-faceted role of the modern university (UPE Publikasiereeks B13). Port Elizabeth: Universiteit van Port Elizabeth.

Rossouw, HW 1993. Universiteit, wetenskap, kultuur. Kaapstad: Tafelberg-Uitgewers. 
Sayer, J 1999. Linking universities across Europe. Principles, practicalities and perspectives, in Smith, D \& Langslow, AK (eds) The idea of a university (Higher Education Policy Series 51). London: Jessica Kingsley Publishers, 68-90.

SAUVCA (South African Universities Vice-Chancellors Association) .2004. Comments on the revised framework for higher education institutions (Appendix A). Pretoria: SAUVCA.

Sellschop, JPF 1995. Diversity in South African universities: the dilemmas of choice regarding teaching and research, in The role of university in South Africa amidst the uncertainties of transition. Pretoria: Committee of University Principles, 31-46.

Shore, P 1992. The myth of the university. Ideal and reality in higher education. Lanham: University Press of America.

Smith, D 1999. The changing idea of a university, in Smith, D \& Langslow, AK (eds) The idea of a university (Higher Education Policy Series 51). London: Jessica Kingsley Publishers, 148174.

Teather, DCB 1999. Higher education in a post-binary era. National reforms and institutional responses (Higher Education Policy Series 38). London: Jessica Kingsley Publishers.

THES (Times Higher Education Supplement) Daily Newsletter. Wed. 6 Oct. 2004. Breakaway warning from Oxford college head.

THES (Times Higher Education Supplement) Daily Newsletter. Wed. 18 Feb. 2004. French intellectuals attack 'war on intelligence'.

UNISA 2004a. Letter dated 01 September 2004, from the Chair, Executive Committee of Senate, to Prof. 1 Molamo, Registrar (Academic) (reference ORT 12-16), informing the latter of the appointment of the Aristides to UNISA.

UNISA 2004b. Press Statement, dated 5 October 2004, and signed by the Pincipal and ViceChancellor, N Barney Pityana, on the appointment of the Aristides to UNISA.

UNISA 2004c. Parliamentary Question 782 (Access Number N1132E), on the appointment of the Aristides to UNISA, with UNISA's answers.

UNISA 2004d. Letter dated 02 December 2004, from Prof. 1 Molamo, Registrar (Academic), to Christo Lombaard, University of Pretoria, titled "Research Fellowships: President Jean-Bertrand Aristide and Mrs Mildred T Aristide".

Verger, J 1978: Universiteiten in de middeleeuwen. Bussum: Fibula - Van Dishoeck.

Visagie, PJ 1990. The mission of the university and the critique of culture. Acta Academica 22/1, March 1990, 114-134.

von Blum, P 1986. Stillborn education. A critique of the American research university. Lanham: University Press of America.

Waters, M. 2000: Globalization (second edition). London: Routledge.

Wethmar, CJ 1996. Wat het Athene met Jerusalem te doen? Enkele histories-sistematiese gesigspunte in verband met die vraag of die teologie aan die universiteit tuishoort. Skrif en Kerk 17/2, 1996, 473-490.

\section{Christo Lombard}

Christian Spirituality

University of South Africa

PO Box 392, UNISA, 0003

Tel.: +2712429 4308

E-mail: lombacjs@UNISA.ac.za 